A. А. Хлєбников, аспірант кафедри політології та філософії, Харківський регіональний інститут державного управління Начіональної академії державного управління при Президентові Украӥни, м. Харків

DOI: $10.32702 / 2306-6814.2018 .24 .125$

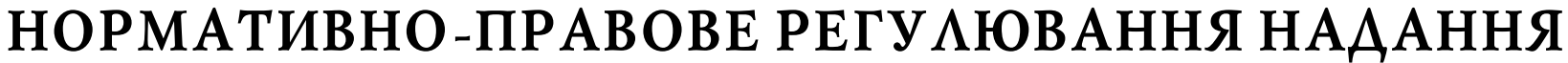

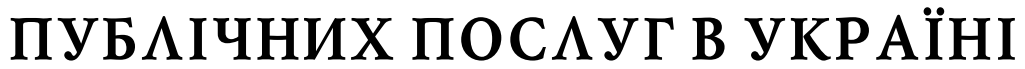

\author{
A. Khliebnykov, \\ Postgraduate student of Political Science and Philosophy Chair, Kharkiv Regional Institute \\ for Public Administration of National Academy for Public Administration Under the President of Ukraine, Kharkiv
}

\section{NORMATIVE-LEGAL REGULATION OF THE PROVISION OF PUBLIC SERVICES IN UKRAINE}

\begin{abstract}
Проблема ефективності діяльності публічних органів влади і послуг, що надаються ними, не є новою, проте особливу актуальність визначена проблема набула саме в останні двадцять років. Саме у цей час стало зрозумілим, що якісні послуги є головним продуктом і водночас основним критерієм діяльності органів публічної влади. Відповідно до цього відбувалось реформування публічного управління у багатьох країнах. Зараз подібне реформування відбувається в Україні, що потребує, з одного боку, вивчення зарубіжного досвіду, з іншого боку, дослідження сьогоденних проблем і можливостей для підвищення ефективності надання публічних послуг усередині України. Також у сучасній державі з ринковою економікою ринок публічних послуг функціонує в рамках існуючих відносин власності і розвивається за законами ринкового господарства. Стан ринку публічних послуг формується з великої кількості інституційних елементів, які представляють собою систему установ і організацій, що забезпечує всю сукупність діяльності людини, взаємодій держави, індивідів і соціальних груп з метою максимізації задоволення матеріальних і духовних потреб людини. Тому дуже важливим питанням є створення належної нормативно-правової бази надання публічних послуг.
\end{abstract}

The problem of the effectiveness of public authorities and the services provided by them is not new, but this problem has become particularly acute in the last twenty years. It was at this time that it became clear that high-quality services were the main product and at the same time the main criterion for the activities of public authorities. Accordingly, there was a reform of public administration in many countries. Now, such reformation takes place in Ukraine, which requires, on the one hand, the study of foreign experience, on the other hand, the study of current problems and opportunities for improving the efficiency of providing public services within Ukraine. Recent studies in this area make it possible to draw two basic conclusions. Firstly, the quality of public services, provided to citizens, is unsatisfactory, especially in the social sphere. According to the experts, the main reasons for this, alongside with a bulk of objective challenges, such as an unfavorable general economic situation in the country, lack of legislatively consolidated social guidelines for public authorities' activity, absence of competition in the sphere of public service provision, there are a number of subjective reasons, specifically, lack of accountability of state agencies' officials who are to provide services, their passivism, apathy, reluctance to solve the citizens' problems. Besides, the quality of services is affected negatively by a low level of partnership between nongovernmental organizations, public authorities and local governments, and representatives of the private sector. Also, there is no real mechanism for studying the needs of the population for public services. Secondly, factors that would, to a large extent, promote improvement of the quality of public service provision are upgrading of the legal framework in effect, aimed at reduction of bureaucratic procedures for obtaining services, and strengthening of public officials' responsibility for a low quality of service provision, as well as enhancement of public control over service provision and participation of nongovernmental organizations in this process. Determining and analysis of the main kinds of this participation should become the subject of further research in the above problem range. Therefore, a very important issue is the creation of a proper legal and regulatory framework for the provision of public services.

Ключові слова: публічні послуги, сочіальні послуги, норматиВно-правове регулюВання, надання послуг, органи публічної Влади, законодавство.

Key words: public services, social services, legal regulation, provision of services, public authorities, legis/ation.

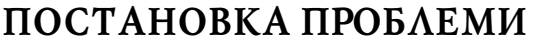

Сьогодні проблема правового регулювання соціально-економічного розвитку як українських міст, так і в цілому держави набуває практичного значення.
Конституцією [7, ст. 1] Україна визнана соціальною державою, причому Основний Закон нашої країни грунтується на ідеї захисту прав людини та підкреслює соціальну спрямованість України: держава забезпечує 
соціальну спрямованість економіки [7, ст. 12], громадяни України мають право на задоволення соціальних інтересів [7, ст. 36], на соціальний захист, що включає право на забезпечення їх у разі повної, часткової або тимчасової втрати працездатності, втрати годувальника, безробіття з незалежних від них обставин, а також у старості [7, ст. 46]. Також Конституція України закріплює такі соціальні гарантії як право на житло, достатній життєвий рівень для себе і своєї сім'ї, медичну допомогу, медичне страхування, освіту та ін. [7, ст. 47-54]. Таким чином, можна підкреслити, що людина та її потреби є пріоритетом діяльності держави та її інститутів.

Між тим, й досі, на жаль, більшість з цих соціальних гарантій не $є$ розкритими у законодавчо закріплених соціальних стандартах. Зазначений фракт не тільки спричиняє негативні соціальні наслідки, але і значно ускладнює реалізацію проголошеного курсу на європейську інтеграцію України. Адже в Європейському Союзі на цих правових нормах засновано всі дії держави в соціальній сорері. Причому чітко закріплені соціальні стандарти життя не можуть переглядатися жодним новим урядом.

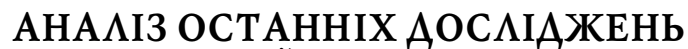 І ПУБ $А$ ІАЦІЙ}

Питання, пов'язані з наданням публічних послуг розглядаються в працях багатьох як вітчизняних, так і зарубіжних дослідників, зокрема, такі: В. Дьяченко, Дж. М. Кларк, Р. Коуз, Л. Кулачок, Ф. Ліст, С. Медянцева, А. Павлова, Є. Сороко, А. Шастітко та ін.

\section{META CTATTI}

Метою статті $€$ розгляд особливості нормативноправового забезпечення надання публічних послуг в Україні.

\section{ВИКААА ОСНОВНОГО MATEPIA $\Lambda$ У}

У переважній більшості країн світу, зокрема країнах пострадянського простору, дуже складно говорити про стабільне інституційне середовище або ефективну систему формальних правил стосовно надання публічних послуг. Більш важливими їх характеристиками тут $\epsilon:$

1) домінування такого співвідношення фрормальних і нефрормальних правил, коли вони вступають у систематичне протиріччя один з одним;

2) вибіркове застосування формальних правил, що перешкоджає реалізації принципу верховенства права.

З приводу останнього Дж. Роулс визначає правову державу або принцип верховенства права через такі постулати [17]: 1) інваріантність поведінки в регламентованій законом ситуації, 2) прецедентний характер вирішення судових спорів; 3) визнання легітимного покарання як єдино можливого.

Відзначимо, що міжнародні стандарти соціальних прав громадян закріплено переважно в правових актах Організації Об'єднаних Націй $(\mathrm{OOH})$ і Міжнародної Організації Праці (МОП). Більшість з них діють уже кілька десятиріч. Серед основних документів, які рег- ламентують соціальні права та свободи громадян в усьому світі, варто виділити такі:

- Загальна декларація прав людини (прийнята у 1948 р.) [4];

- Європейська соціальна хартія (прийнята у 1961 році, переглянута у 1996 році, ратифікована Україною у 2006 р.) [2];

- Європейський кодекс соціального забезпечення (прийнятий у 1964 р., переглянутий у 1990 р.) [3];

- Хартія соціального забезпечення (прийнята у 1982 р.) [15];

- Хартія Співтовариства про основні соціальні права працівників (прийнята у 1989 р.) [16];

- Хартія основних прав Європейського Союзу (прийнята у 2000 р.) [14] та інші.

Серед вищенаведених документів особливо місце займає Загальна декларація прав людини, яка за своєю сутністю, $є$ фундаментом визнання, визначення та захисту прав людини. У Декларації наведено комплекс прав людини, серед яких важливе місце займає право людини на соціальне забезпечення.

У статті 22 Декларації зокрема відзначається: "Кожна людина, як член суспільства, має право на соціальне забезпечення і на здійснення необхідних для підтримання її гідності і для вільного розвитку її особи прав у економічній, соціальній і культурній галузях за допомогою національних зусиль і міжнародного співробітництва та відповідно до структури і ресурсів кожної держави" [4].

Загальна декларація прав людини вперше сформувала соціальні еталони, до яких повинне прагнути суспільство, конкретизувала соціальні параметри, вказуючи, що кожна людина має право на працю, на вільний вибір роботи, на справедливі і сприятливі умови праці та на захист від безробіття; на рівну оплату за рівну працю; на відпочинок і дозвілля, включаючи право на розумне обмеження робочого дня та на оплачувану періодичну відпустку; на такий життєвий рівень, включаючи їжу, одяг, житло, медичний догляд та необхідне соціальне обслуговування, який $є$ необхідним для підтримання здоров'я і добробуту її самої та її сім'ї, і право на забезпечення в разі безробіття, хвороби, інвалідності, вдівства, старості чи іншого випадку втрати засобів до існування через незалежні від неї обставини; на освіту; вільно брати участь у культурному житті суспільства, втішатися мистецтвом, брати участь у науковому прогресі і користуватися його благами; на соціальний порядок та ін. [4, ст. 22-28].

Безумовно, Декларація має рекомендаційний статус, і не накладає будь-яких зобов'язань на жодну країну світу, але вже в 1966 році на її основі було прийнято Міжнародний пакт про економічні, соціальні і культурні права [8], який було ратифріковано Указом Президії Верховної Ради Української РСР у 1973 р. У цьому Пакті сорормулювало конкретні соціальні стандарти, яким повинні відповідати країни, що ратифікували цей документ.

Разом з Міжнародним пактом про цивільні та політичні права, цей документ запровадив поширену класифрікацію прав людини на соціальні, цивільні, політичні, економічні і культурні. При цьому до соціальних прав віднесено такі: 
- право кожної людини на соціальне забезпечення, включаючи соціальне страхування [8, ст. 9];

- право працюючих матерів на оплачувану відпустку або відпустку з достатньою допомогою по соціальному забезпеченню [8, ст. 10];

- право захисту дітей від економічної і соціальної експлуатації [8, ст. 10];

- право на достатній життєвий рівень, що включає достатнє харчування, одяг і житло, і на неухильне поліпшення умов життя [8, ст. 11];

- право на найвищий досяжний рівень фрізичного i психічного здоров'я [8, ст. 12];

- право на освіту, підкреслюючи при цьому, що початкова освіта повинна бути обов' язкова і безкоштовна для всіх, середня освіта в її різних формах, включаючи професійно-технічну середню освіту, повинна бути доступною для всіх громадян [8, ст. 13].

Таким чином, Пактом регламентовано обов'язки держави щодо соціального захисту як кожної людини, так і окремих уразливих категорій.

Зазначимо, що Європейським Союзом та Радою Європи, на додачу до вищенаведених, було ухвалено і низку своїх нормативно-правових актів щодо соціальних стандартів.

Важливим документом, що гарантує розвиток соціальної сорери та передбачає захист прав людини $€$

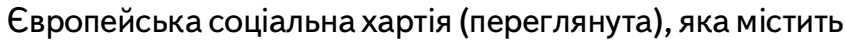
31 принцип [2, ч. 1], на яких будується вся європейська соціальна система:

Згідно з цією Хартію, всі люди, зокрема, мають такі права: заробляти собі на життя професією, яку вони вільно обирають; на захист від бідності та соціального відчуження; на житло; на користування послугами соціальних служб; на належні умови для професійної підготовки; на соціальну та медичну допомогу.

Усі працюючі, згідно з цією Хартією, мають право на таке: безпечні та здорові умови праці; гідне ставлення до них на роботі; захист у випадках звільнення; захист своїх вимог у разі банкрутства роботодавця; рівні можливості та рівне ставлення до них у вирішенні питань щодо працевлаштування та професії без дискримінації за ознакою статі; свободу об'єднання в національні або міжнародні організації для захисту своїх економічних і соціальних інтересів; соціальне забезпечення; справедливі умови праці; справедливу винагороду, яка забезпечить достатній життєвий рівень для них самих та їхніх сімей.

Зауважимо, що під час ратифрікації Хартії Україна взяла на себе зобов'язання вважати вищенаведені принципи декларацією цілей, до здійснення яких вона прагнутиме всіма відповідними засобами [5, ст. 1], у тому числі шляхом надання якісних публічних послуг.

Між тим, ця категорія в українському законодавстві практично відсутня. Під час дослідження було переглянуто майже всю існуючу нормативно-правову базу українського законодавства стосовно цього питання. Серед більше ніж 100000 документів термін "послуги" зустрічається лише у 3769 документах, причому сам цей термін "публічні послуги" не тлумачиться взагалі. Таким чином, можна з упевненістю стверджувати, що норма- тивно-правова база публічних послуг та система їх надання у країні відсутня, як і відсутнє юридичне тлумачення самого терміна.

Між тим, досліджуючи поняття "публічні послуги", важливо наголосити на тому, що в українському законодавстві сьогодні існує велика кількість видів цих специфічних послуг, які надаються на всіх рівнях. Так, зокрема, до публічних послуг, які надаються державними (комунальними) установами відносять: соціальні; дозвільні; ліцензійні, легалізаційні; акредитаційні; атестаційні; реєстраційні; експертні; консультативні та інформативні; погоджувальні.

Як було зазначено вище, структурна характеристика розподілу компетенції та повноважень між органами державної виконавчої влади і органами місцевого самоврядування за рівнями виявляє ще один окремий різновид послуг - муніципальні, які надаються виключно органами місцевого самоврядування територіальній громаді, громадянам з метою задоволення їх потреб.

У контексті дослідження важливим $€$ не лише розгляд механізму надання якісних публічних послуг, але й з'ясування соціальних наслідків цього процесу. 3 нашої точки зору, за соціальними наслідками публічні послуги, які надаються органами державної влади та місцевого самоврядування, утворюють чотири ранги.

Перший (нижчий). Репутація, імідж, довіра, надійність, впевненість стосовно адміністративної установи, яка призначена надавати державні послуги.

Висока впевненість зумовлює позитивні наслідки. Імідж адміністративної установи містить такі елементи:

- ефективність діяльності як цілісної структури, так і окремих її функціональних одиниць;

- наявність єдиної стратегії діяльності таїї якість;

- ставлення працівників до своєї установи таїї керівників;

- імідж керівників;

- впорядкованість та цілісність державної організації;

- рівень організаційної культури, зокрема етичні норми;

— врахування потреб, менталітету громадян та історичних особливостей місцевості.

Другий (середній). Скарги або апеляції від громадськості, доступність послуг.

Дані категорії є складовими зворотного зв'язку, щодо реалізації державної-регіональної політики. Одним з інструментів державної регіональної політики $€$ послуги. Оцінка політики здійснюється через аудит адміністративної діяльності. До індикаторів аудиту адміністративної діяльності належать: недоліки в послугах державних службовців та посадових осіб, велика кількість скарг або апеляцій від громадськості, збільшення витрат на утримання адміністрацій різного рівня [1]. Намагання усунути недоліки та їх реальне усунення завжди сприймається схвально і викликає зростання попиту на управлінські послуги. Це спонукає державних службовців до розширення пропозиції послуг. Гармонія пропозиції та попиту управлінських послуг відображає їх якість та успішність застосування механізму їх надання. 
Третій (вищий). Політичне й соціально-правове становище (статус особи в суспільстві).

Україна взяла курс на розширення демократичних прав і свобод особи, приведення їх змісту у відповідність до міжнародно-правових стандартів. Це передбачає посилення взаємної відповідальності держави й особи. Великого значення набуває подолання політичної апатії населення. Успішне розв'язання цієї проблеми визначається діяльністю апарату державного управління. Рівень роботи якого з одним із важливих критеріїв загальної культури будь-якого суспільства. А також політичного і соціально-правового становища особи в ньому. Ось чому підвищення ефективності і якості роботи всіх ланок державної системи управління, удосконалення ії̈ структури, організації і практичної діяльності є складовим елементом загального процесу поліпшення якісних характеристик сучасного суспільного розвитку країни.

Четвертий (найвищий). Рівень соціальної та політичної напруженості суспільстві.

Ступінь нерозв'язаності проблем, які розглядались у попередніх послугах, більшою чи меншою мірою зумовлюють рівень напруженості в суспільстві. Більшість населення відчуває на собі негативні наслідки некомпетентного управління, неякісного та несвоєчасного надання послуг, безвідповідальної та зруйнованої поведінки певної частини державних службовців та посадових осіб. Зрештою це призводить до втрати довіри до влади, ганьбить її імідж в очах громадян, породжує політичну та соціальну напруженість у суспільстві [1].

Отже, необхідною умовою процесу надання публічних послуг будь-якого виду є передбачення та врахування соціальних наслідків цього процесу, а також розширення соціокомунікаційної сорери через створення системи контактів влади з громадянами. Проте в Україні ще відсутня ефективна система надійних контактів влади з громадянами та їх організаціями, що породжує недовіру громадян до державної служби та інститутів держави. Тому завдання органів державної влади та місцевого самоврядування полягає у тому, щоб виправдовувати своє існування за допомогою підвищення якості публічних послуг - головної умови фрормування довіри населення до влади.

Ефективність функціонування суспільства, прискорення його рефрорматорського поступу багато в чому залежить від дійового функціонування системи державної служби, яка виступає одним із основних елементів державного управління. Протягом останніх років у західних країнах напрацьовано обов'язкових вимог до правового регулювання адміністрацій та процедури, зокрема з надання адміністративних послуг, тобто принципів (або обов'язкових стандартів), у разі незабезпеченості яких важко говорити про якість такого регулювання, а отже, і створення умов для ефективної діяльності адміністрації, особливо про захист прав та свобод громадян і приватних інституцій у відносинах з державою. Для України законодавче впорядкування діяльності органів виконавчої влади - одне з найважливіших завдань конституційної реформи.

Слід зауважити, що для впорядкування адміністративно-процедурних відносин у сфері нормативної діяль- ності органів виконавчої влади, відносин у справах за ініціативою органів виконавчої влади, а також відносин щодо вирішення органами виконавчої влади справ за зверненнями фрізичних і юридичних осіб, необхідне грунтоване науково-методологічне опрацювання цієї проблематики. Крім того, всі адміністративно-процедурні відносини вимагають належного правового регулювання, і звичайно, оптимальною формою такого акта був би Адміністративно-процесуальний кодекс, який би охопив усі види проваджень. Однак прийняття такого кодексу видається маловірним. Реальнішим у сучасних умовах є прийняття закону України про адміністративну процедуру в органах виконавчої влади та органах місцевого самоврядування. Предмет регулювання відповідного законодавчого акта повинен визначати стандарти надання послуг і стосуватися проваджень у справах: за заявами фрізичних та юридичних осіб, у тому числі з надання публічних послуг; за ініціативою органів виконавчої влади й місцевого самоврядування, в тому числі й у порядку здійснення контрольних повноважень, щодо фрізичних та юридичних осіб; за скаргами фрізичних та юридичних осіб на рішення, дії та бездіяльність органів влади.

\section{ВИСНОВКИ ТА ПЕРСПЕКТИВИ

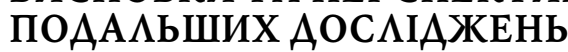

Сьогодні, на жаль, у вітчизняному правознавстві відсутнє юридичне тлумачення терміна "публічні послуги", що надає цій категорії характеру певної соціальної абстракції і невизначеності. За цих умов правовою основою надання публічних послуг в Україні сьогодні $є$, перш за все, Конституція України [7], Закони України "Про місцеве самоврядування в Україні" [11], "Про місцеві державні адміністрації" [12], "Про захист прав споживачів" [9], "Про соціальні послуги" [13] та інші нормативно-правові акти.

Водночас в адміністративному праві провідних країн Заходу (Франція, Англія тощо) правовий інститут публічних послуг $є$ досить розробленим і діє протягом багатьох десятиліть. Цей інститут доволі точно відображає місце демократичної держави у відносинах з людиною і суспільством. Людина все більшою мірою починає розглядатися як клієнт та споживач послуг, що надаються державними, регіональними та місцевими установами і відомствами, і у зв'язку з цим діяльність установ розглядається через призму задоволення потреб і конкретних запитів споживача. Успішність роботи цих установ, підприємств і відомств залежить від додаткових функцій і розвитку нетрадиційних видів обслуговування, що збільшують результат. Отже, становлення такого інституту, як надання публічних послуг - новий напрям розвитку правового поля та інституційного середовища в Україні.

\section{Література:}

1. Губа О.П. Керівні кадри державної служби як рушійна сила адміністративної реформи / О.П. Губа / / Актуальні проблеми державного управління: зб. наук. праць. - Х.: Вид-во ХарРІ НАДУ "Магістр", 2003. - № 3 (18). - С. $186-191$.

2. Європейська соціальна хартія / / Відомості Верховної Ради України. - 2007. — № 51. - Ст. 2096. 
3. Європейський кодекс соціального забезпечення [Електронний ресурс]. - Режим доступу: http:// zakon1.rada.gov.ua/cgi-bin/laws/main.cgi?nreg=994_651\&p=1237807844867395

4. Загальна декларація прав людини: прийнята і проголошена резолюцією 217 A (III) Генеральної Асамблеї ООН від 10 грудня 1948 р. [Електронний ресурс]. Режим доступу: http://zakon 1.rada.gov.ua/cgi-bin / laws /main.cgi?nreg=995_015

5. Закон України "Про ратифрікацію Європейської соціальної хартії (переглянутої)" / / Відомості Верховної Ради України. - 2006. - № 43. - Ст. 418.

6. Конвенція про захист вимог працівників у випадку неплатоспроможності роботодавця [Електронний ресурс]. - Режим доступу: http:/ / zakon1.rada.gov.ua/ cgi-bin /laws/main.cgi?nreg=993_286\&p=1238577737175929

7. Конституція України : прийнята на п'ятій сесії Верховної ради України 28 червня 1996 р. // Відомості Верховної Ради України. - 1996. - № 30. - Ст. 141.

8. Міжнародний пакт про економічні, соціальні і культурні права: [Електронний ресурс]. - Режим доступу: http://zakon1.rada.gov.ua/cgi-bin /laws / main.cgi?nreg=995_043\&p=1237807844867395

9. Про захист прав споживачів: Закон України від 12 травня 1991 року № 1023-XII / / Відомості Верховної Ради УРСР. - 1991. - № 30. - Ст. 379.

10. Про заходи щодо впровадження Концепції адміністративної реформи в Україні [Електронний ресурс]: Указ Президента України від 22 липня 1998 р. №810/ 98 (із змінами і доповненнями). - Режим доступу: http:/ /www.liga.kiev.ua

11. Про місцеве самоврядування в Україні: Закон України від 21 травня 1997 року № 280/97-ВР / / Відомості Верховної Ради України. - 1997. - № 24. - Ст. 170.

12. Про місцеві державні адміністрації: Закон України від 09 квітня 1999 року № 586-XIV / / Відомості Верховної Ради України. - 1999. - № 20-21. Ст. 190.

13. Про соціальні послуги: Закон України від 19 червня 2003 року № 966-IV / / Відомості Верховної Ради України. - 2003. - № 45. - Ст. 358.

14. Хартія основних прав Європейського Союзу [Електронний ресурс]. - Режим доступу: http:// zakon 1.rada.gov.ua/cgi-bin/laws/main.cgi?nreg=994_524\&p=1237807844867395

15. Хартія соціального забезпечення [Електронний ресурс]. - Режим доступу: http://zakon1.rada.gov.ua/ cgi-bin/laws/main.cgi?nreg=995_418

16. Хартія Співтовариства про основні соціальні права працівників [Електронний ресурс]. - Режим доступy: http: / / zakon 1.rada.gov.ua/cgi-bin/laws/main.cgi?nreg=994_044\&p=1237807844867395

17. Rawls J. A Theory of Justice / J. Rawls. - Cambridge, Mass., 1971. - $607 \mathrm{p}$.

References:

1. Guba, O.P. (2003), "Leading cadres of the civil service as the driving force of administrative reform", Aktual'ni problemy derzhavnoho upravlinnia, vol. 3, pp. 186-191.
2. Council of Europe (1961), "European Social Charter", available at: https://www.coe.int/en/ web/turin-european-social-charter (Accessed 01 December 2018).

3. Council of Europe (1968), "The European Code of Social Security", available at: https://www.coe.int/en / web/conventions/full-list/-/conventions/treaty/048 (Accessed 01 December 2018).

4. United Nations (1948), "Universal Declaration of Human Rights", available at: http://www.un.org/en/ universal-declaration-human-rights (Accessed 01 December 2018).

5. The Verkhovna Rada of Ukraine (2006), The Law of Ukraine "On ratification of the European Social Charter (revised)", Vidomosti Verkhovnoi Rady Ukrainy, vol. 43, p. 418.

6. International Labour Organization (1992), "Protection of Workers' Claims (Employer's Insolvency) Convention", available at: https://www.ilo.org/dyn / normlex/en/f? $p=$ NORMLEXPUB:12100:0::NO::P12100_ILO_CODE:C173 (Accessed 01 December 2018).

7. The Verkhovna Rada of Ukraine (2006), "The Constitution of Ukraine", Vidomosti Verkhovnoi Rady Ukrainy, vol. 30, p. 141.

8. United Nations (1966), "International Covenant On Economic, Social and Cultural Rights", available at: https:/ /www.ohchr.org/en/professionalinterest/pages / cescr.aspx (Accessed 01 December 2018).

9. The Verkhovna Rada of Ukraine (1991), The Law of Ukraine "On consumer rights protection", Vidomosti Verkhovnoi Rady Ukrainy, vol. 30, p. 379.

10. The President of Ukraine (1998), "The Decree "On measures to implement the Concept of Administrative Reform in Ukraine"", available at: http://zakon.rada.gov.ua/laws/show/810/98 (Accessed 01 December 2018).

11. The Verkhovna Rada of Ukraine (1997), The Law of Ukraine "On local self-government in Ukraine", Vidomosti Verkhovnoi Rady Ukrainy, vol. 24, p. 170.

12. The Verkhovna Rada of Ukraine (1999), The Law of Ukraine "On local state administrations", Vidomosti Verkhovnoi Rady Ukrainy, vol. 20-21, p. 190.

13. The Verkhovna Rada of Ukraine (2003), The Law of Ukraine "On social services", Vidomosti Verkhovnoi Rady Ukrainy, vol. 45, p. 358.

14. European Parliament (2000), "The Charter of Fundamental Rights of the European Union", available at: http://www.europarl.europa.eu/charter/pdf/text_en.pdf (Accessed 01 December 2018).

15. The Verkhovna Rada of Ukraine (1992), "The Charter of social security", available at: http://zakon1.rada.gov.ua/cgi-bin/laws/main.cgi?nreg=995_418 (Accessed 01 December 2018).

16. The European Council (1989), "Community Charter on Fundamental Social Rights of Workers", available at: http://aei.pitt.edu/4629/1/4629.pdf (Accessed 01 December 2018).

17. Rawls, J. (1971), A Theory of Justice, Harvard University Press, Cambridge, Mass, USA.

Стаття надійшла до редакцї̈ 04.12.2018 p. 